\title{
Clinical applications of serum theophylline measurement by high pressure liquid chromatography
}

\author{
SHEILA A. MCKENZIE, A. T. EDMUNDS, EIVOR BAILLIE, AND J. H. MEEK \\ From the Department of Paediatrics and Neonatal Medicine, Institute of Child Health, Hammersmith Hospital, \\ London
}

SUMMARY Serum theophylline concentration was measured in children both during treatment of status asthmaticus with intravenous aminophylline, and as outpatients while they were taking oral theophylline compounds for long-term management of asthma. The clinical value of the measurements was assessed. Measurement using high-pressure liquid chromatography is simple and requires only a small volume of blood. Knowledge of serum theophylline concentration facilitates careful control of dosage of both intravenous aminophylline during treatment of status asthmaticus, and of oral theophylline in outpatients. It is useful in the evaluation of symptoms which may be due to toxic side effects of treatment. It also makes possible an assessment of patient compliance with prescribed treatment among those whose symptoms have not improved.

Aminophylline has for many years been widely used for the treatment of status asthmaticus. Oral theophylline compounds have not, however, enjoyed the same popularity in the long-term treatment of asthma. Recent trials (Weinberger and Bronsky, 1974; Hambleton et al., 1977) have shown that regular theophylline is an effective treatment for continuous perennial asthma in children and it has proved at least as effective as sodium cromoglycate. Serum theophylline levels of $10-20 \mu \mathrm{g} / \mathrm{ml}$ are considered to be necessary for maximum therapeutic effect (Turner-Warwick, 1957; Nicholson and Chick, 1973; Mitenko and Ogilvie, 1973) and when the upper limit of this range is exceeded, toxic symptoms occur with increasing frequency (Zwillich et al., 1975).

Because the half-life of theophylline in serum can vary by up to sevenfold in different individuals (Ellis et al., 1976), measurement of serum theophylline is necessary to individualise treatment regimens. A method for rapid measurement on small blood samples would clearly be an advantage both in the outpatient management of asthmatic children and in the treatment of status asthmaticus when aminophylline is used. We report our experience over 9 months using a high-pressure liquid chromatograph to monitor serum theophylline concentration of asthmatic children attending this hospital.

Received 14 September 1977

\section{Method}

$50 \mu \mathrm{g}$ of serum was mixed with $100 \mu 11.0 \mathrm{M}$ trichloracetic acid to precipitate proteins, and after centrifugation $40 \mu$ l of the supernatant was injected into the chromatograph. The chromatographic system used was an ACS LC 750 modular liquid chromatograph (Applied Chromatography Systems Ltd., Luton, England). This consisted of a Specac 30.100 constant volume injection valve (Spectroscopic Accessory Company, Orpington, England), a precolumn of Co-Pell ODS $5 \mathrm{~cm} \times 2 \cdot 1 \mathrm{~mm}$ (Whatman Ltd) and a main column of Partisil-10 ODS $25 \mathrm{~cm} \times 4.6 \mathrm{~mm}$ (Whatman Ltd). The mobile phase $(6.5 \mathrm{v} / \mathrm{v}$ acetonitrile in $0.01 \mathrm{M}$ sodium acetate pH 4.0 ) was pumped at $3.0 \mathrm{ml} / \mathrm{min}$ and the ultraviolet detector was set at an absorbance range of $0-0.01 \mathrm{U}$. The precolumn was repacked after each 100 samples and the main column showed no deterioration after 1000 samples.

The theophylline peak appeared 6 minutes 40 seconds after injection (Fig. 1a). The calibration was linear for theophylline concentration up to $70 \mu \mathrm{g} / \mathrm{ml}$. Thus only one standard $(20 \mu \mathrm{g} / \mathrm{ml}$ theophylline) was used. This was run before every six samples. The precision of the method was assessed by performing 22 replicate analyses on one specimen during one month. The estimates of theophylline concentrations showed a coefficient of variation of $3 \cdot 1 \%$ (mean $15 \cdot 5 \mu \mathrm{g} / \mathrm{ml}$. SD $0.49 \mu \mathrm{g} / \mathrm{ml}$ ). 

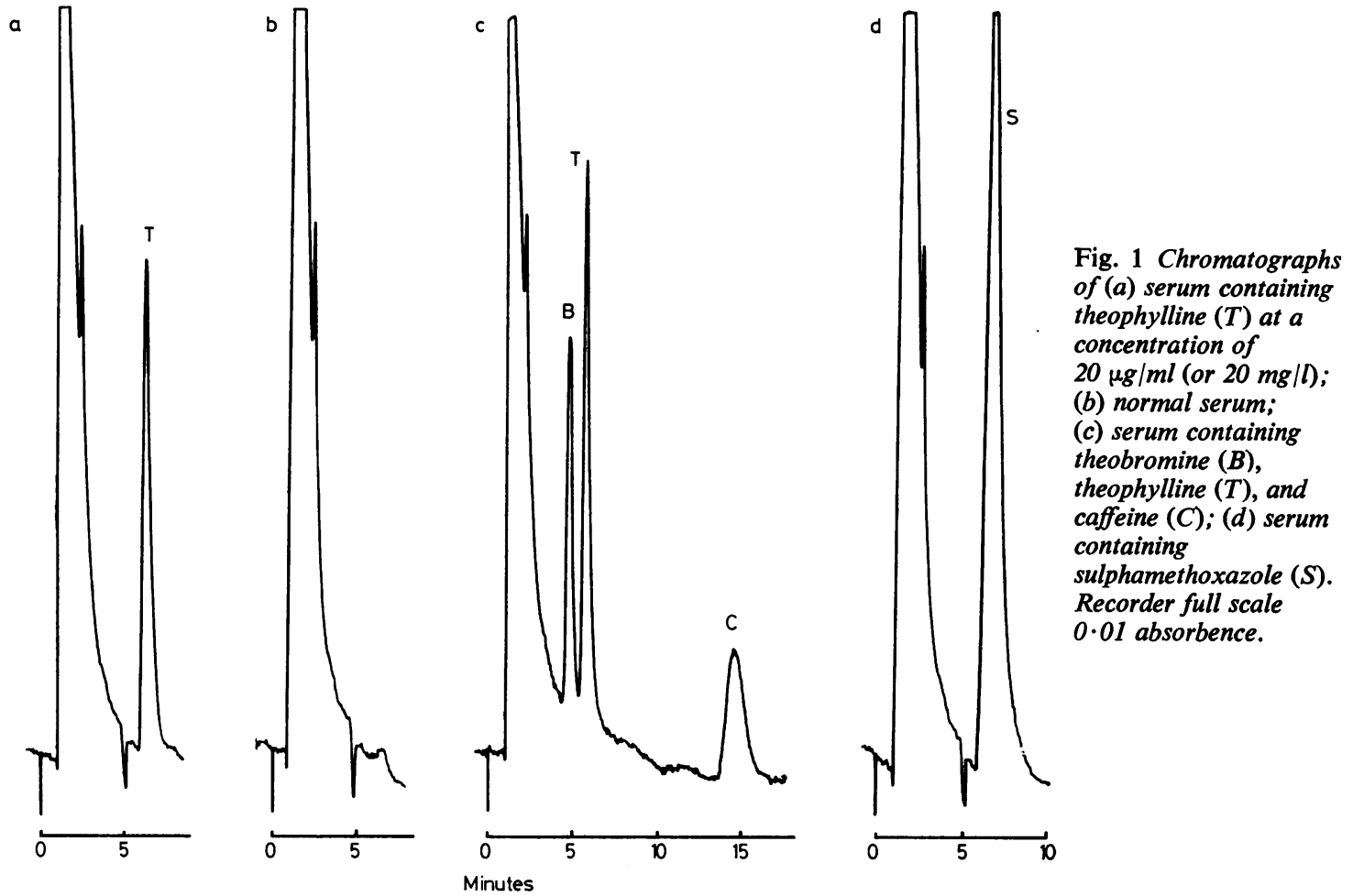
of (a) serum containing theophylline $(T)$ at a concentration of $20 \mu \mathrm{g} / \mathrm{ml}$ (or $20 \mathrm{mg} / \mathrm{l})$;

(b) normal serum;

(c) serum containing theobromine $(B)$, theophylline $(T)$, and caffeine $(C) ;(d)$ serum containing sulphamethoxazole $(S)$. Recorder full scale 0.01 absorbence.

Normal components of serum did not interfere significantly with the theophylline measurements. Specimens from 21 normal subjects produced only small deflections, ranging from 0 to $1 \cdot 1 \mu \mathrm{g} / \mathrm{ml}$ at the position of the theophylline peak (Fig. 1b). Related compounds: caffeine, theobromine, dyphylline, xanthine, hypoxanthine, 3-methylxanthine, and uric acid caused no interference, nor did commonly used drugs such as paracetamol and phenobarbitone (Fig. 1c). However, sulphamethoxazole did produce a peak in the same position as that of theophylline (Fig. 1d).

\section{Patients and results}

Twenty-four children aged $3 \frac{1}{2}$ to 14 years, who were admitted for treatment of status asthmaticus, were given intravenous aminophylline. 13 patients had not received theophylline before admission. The first 3 were treated with bolus doses of $4 \mathrm{mg} / \mathrm{kg}$ aminophylline followed by continuous infusions of $0.7 \mathrm{mg} / \mathrm{kg}$ per hour. In view of the suboptimal serum theophylline concentration obtained when measured after 2 hours after treatment (Fig. 2) the bolus dose of aminophylline in subsequent patients was increased, first to 5 and then to $6 \mathrm{mg} / \mathrm{kg}$, and the infusion to $0.9 \mathrm{mg} / \mathrm{kg}$ per hour.

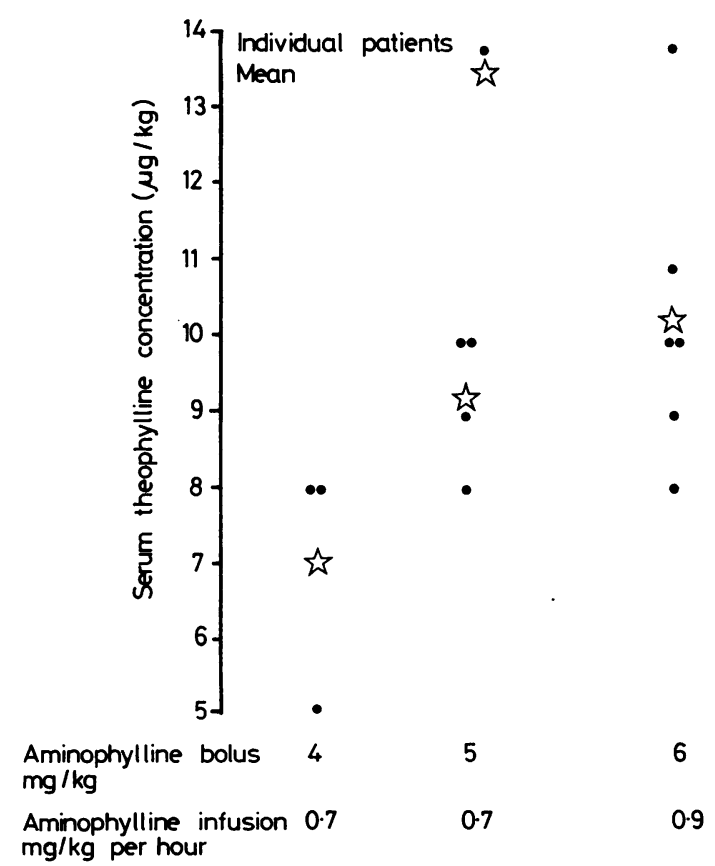

Fig. 2 Serum theophylline concentration after 2 hours' continuous treatment with intravenous aminophylline for patients who had received no theophylline before admission. 
Ten patients had been receiving oral choline theophyllinate and one had received aminophylline intravenously during the 8 hours before admission. Serum theophylline in blood samples taken at the time of admission in these 11 patients ranged from $<1$ to $12 \mu \mathrm{g} / \mathrm{ml}$ (Table 1 ). In 4 patients the result was available before treatment and a bolus dose of aminophylline, considered enough to produce a therapeutic level of serum theophylline was given. In 7 the results were not available, but with a knowledge of the time and size of the last theophylline dose the appropriate dose of aminophylline was predicted. In Case 3 the serum theophylline on admission was underestimated, and in Cases 4, 6, and 11 it was overestimated.

In 13 patients serum theophylline was measured after 12-48 hours of continuous infusion of aminophylline at $0.7-0.9 \mathrm{mg} / \mathrm{kg}$ per hour. The mean serum theophylline concentration in these patients 2 hours after starting treatment was $10.6 \mu \mathrm{g} / \mathrm{ml} \pm$ $2 \cdot 6 \mathrm{SD}$ and it had fallen to $8 \cdot 5 \pm 3 \cdot 3 \mathrm{SD}$ by the second measurement.

Fifty-seven asthmatic children (aged 6 months to 15 years) with perennial symptoms were treated with choline theophyllinate. 15 children were aged 4 years or under. They were treated with either $8 \mathrm{mg} / \mathrm{kg}$ four times a day (qds) or $10 \mathrm{mg} / \mathrm{kg}$ three times a day (tds) initially, and serum theophylline ( 2 hours after dose) was within the therapeutic range in all but 4 children. In 2 the concentrations were suboptimal on $8 \mathrm{mg} / \mathrm{kg}$ qds. In these, satisfactory concentrations were achieved when the dose was increased to 12 $\mathrm{mg} / \mathrm{kg}$ qds. 2 patients had concentrations $>20$ $\mu \mathrm{g} / \mathrm{ml}$; one had received too large a dose in error and the other had had only $8 \mathrm{mg} / \mathrm{kg}$.

Fourteen children complained of nausea or vomiting although serum theophylline concentrations measured while they were symptomatic were never $>16 \mu \mathrm{g} / \mathrm{ml}$ and were $<5 \mu \mathrm{g} / \mathrm{ml}$ in 6 patients. Despite these low levels, theophylline had to be withdrawn from 5 patients because the symptoms persisted (Table 2). In the remainder, the symptoms resolved without discontinuing the drug.

In 16 children control of symptoms was unsatisfactory during the first month of treatment with choline theophyllinate. Measurements had shown that in all cases the prescribed dose was adequate when treatment was started. However, repeat measurements when they attended the clinic showed that only 5 of these children had serum theophylline concentrations $>10 \mu \mathrm{g} / \mathrm{ml}$.

\section{Discussion}

High-pressure liquid chromatography has several advantages over the spectrophotometric method of Schack and Waxler (1949) in the measurement of theophylline. Only a small amount of serum or plasma $(50 \mu l)$ is needed. The result can be obtained within 10 minutes and compounds such as caffeine and theobromine do not interfere. Thus there is no need to ban coffee, tea, or chocolate during periods when measurements are being made. The only compound which caused significant interference was sulphamethoxazole, observed when patients with infected eczema were treated with trimethoprimsulphamethoxazole. The drug must be avoided if measurement of serum theophylline is made.

Table 2 Serum theophylline concentrations in 5 children with persistent vomiting

\begin{tabular}{clc}
\hline $\begin{array}{l}\text { Dose } \\
(\mathrm{mg} / \mathrm{kg})\end{array}$ & $\begin{array}{l}\text { Time since last dose } \\
(\mathrm{h})\end{array}$ & $\begin{array}{l}\text { Concentration } \\
(\mu \mathrm{g} / \mathrm{ml})\end{array}$ \\
\hline 8 & 2 & 16 \\
8 & 2 & 9 \\
10 & 3 & 14 \\
5 & 2 & 3 \\
9 & $2 \frac{1}{2}$ & 13 \\
8 & 2 & 6 \\
\hline
\end{tabular}

*Same child.

Table 1 Serum theophylline concentrations in relation to dose given

\begin{tabular}{|c|c|c|c|c|c|}
\hline Case no. & $\begin{array}{l}\text { Theophylline* } \\
\text { dose } \\
(\mathrm{mg} / \mathrm{kg})\end{array}$ & $\begin{array}{l}\text { Time since } \\
\text { last dose } \\
\text { (h) }\end{array}$ & $\begin{array}{l}\text { Admission } \\
\text { serum theophylline } \\
(\mu \mathrm{g} / \mathrm{ml})\end{array}$ & $\begin{array}{l}\text { Aminophylline } \\
\text { bolus } \\
(\mathrm{mg} / \mathrm{kg})\end{array}$ & $\begin{array}{l}\text { Serum theophylline } \\
\text { after treatment } \\
(\mu \mathrm{g} / \mathrm{ml})\end{array}$ \\
\hline $\begin{array}{l}1 \dagger \\
2 \dagger \\
3 \\
4 \\
5 \dagger \\
6 \\
7 \dagger \\
8 \\
9 \\
10 \\
11\end{array}$ & $\begin{array}{l}0 \cdot 6 / \mathrm{h} \\
5 \cdot 2 \\
4 \cdot 6 \\
4 \cdot 6 \\
7 \cdot 8 \\
5 \cdot 5 \\
5 \cdot 2 \\
5 \cdot 5 \\
3 \cdot 9 \\
5 \cdot 5 \\
4 \cdot 6\end{array}$ & $\begin{array}{l}\text { Continuous } \\
2 \\
3 \\
3 \cdot 5 \\
4 \\
4 \\
4 \\
4 \cdot 5 \\
6 \\
6 \\
8\end{array}$ & $\begin{array}{c}12 \\
8 \\
11 \\
5 \\
8 \\
3 \\
10 \\
1 \cdot 7 \\
4 \\
3 \\
1\end{array}$ & $\begin{array}{l}0 \\
2 \cdot 5 \\
4 \\
2 \\
3 \cdot 5 \\
4 \\
2 \cdot 5 \\
4 \\
5 \\
5 \\
4\end{array}$ & $\begin{array}{r}14 \\
12 \\
14 \\
9 \\
9 \\
10 \\
8 \\
12 \\
6 \\
6 \\
10 \\
10 \\
8\end{array}$ \\
\hline
\end{tabular}

*Aminophylline contains $85 \%$ theophylline; choline theophyllinate contains $65 \%$ theophylline.

†Patients in whom serum theophylline concentration on admission was known at the time of treatment. 
Theophylline has an apparent volume of distribution of approximately $450 \mathrm{ml} / \mathrm{kg}$ and a mean plasma clearance rate of $87 \pm 35 \mathrm{ml} / \mathrm{h}$ per $\mathrm{kg}$ (Mitenko and Ogilvie, 1973; Ellis et al., 1976). Thus, for patients in status asthmaticus who have not had theophylline, a bolus dose of $5.6 \mathrm{mg} / \mathrm{kg}$ aminophylline given over 5 minutes, followed by a constant infusion at $0.8-0.9 \mathrm{mg} / \mathrm{kg}$ per hour, would achieve serum theophylline levels of $10 \mu \mathrm{g} / \mathrm{ml} \pm 5$. However, when patients have already had theophylline, a knowledge of the serum theophylline at the time of admission helps in planning treatment to produce an optimum concentration quickly, without the danger of toxic side effects.

It was impossible to predict serum theophylline concentration at the time of admission even though careful inquiry was made about drugs given during the previous 12 hours (Table 2). There was a tendency to overestimate the concentration and to undertreat the patient, but in one case an underestimate was made.

The wide individual variation of plasma clearance for theophylline is clearly shown by the range of serum theophylline concentrations found when the children had received constant infusions for 12 hours or more. This shows continued monitoring is necessary if optimum theophylline concentrations are to be maintained. It is particularly valuable in the assessment of patients who appear unresponsive to treatment.

In the long-term treatment of asthmatic children with choline theophyllinate as outpatients a dose of either $8 \mathrm{mg} / \mathrm{kg}$ qds or $10 \mathrm{mg} / \mathrm{kg}$ tds produces a satisfactory 2-hour post dose serum theophylline concentration (McKenzie et al., 1978). We have now studied 57 patients and found concentrations at 2 hours after a dose outside the therapeutic range in only 3.

Nausea and vomiting are recognised side effects of theophylline overdosage (Zwillich et al., 1975). Their occurrence when serum theophylline concentrations are within the therapeutic range has been described before (Hambleton et al., 1977) and it has been suggested that if the oral theophylline compound is introduced slowly these symptoms can be avoided. 5 children in this series had intractable symptoms in spite of having serum theophylline levels $<16 \mu \mathrm{g} / \mathrm{ml}$, and their symptoms resolved when the drug was discontinued. Thus in the children who show idiosyncratic reaction to theophylline it is of no clinical value. Despite this, when symptoms occur measurement of serum theophylline concentrations will in most cases resolve the question as to whether they are due to toxic side effects or not.
In this series only $5(30 \%)$ of the patients whose symptoms were poorly controlled by theophylline had serum concentrations in the therapeutic range. The other 11 had low concentrations, for which the most likely explanation was that they had not taken their medication. Thus they could not be said to have failed to respond to adequate treatment. Eney and Goldstein (1976) recently showed that therapeutic levels of theophylline were found in only $11 \%$ of a group of outpatients. In a second group who had more supervision and encouragement, the number increased to $42 \%$. The method described makes it possible to have the result of the theophylline measurement available at the time of the outpatient visit. This is of great help in making an 'on the spot' assessment of response to theophylline therapy.

\section{References}

Ellis, E. F., Koysooko, R., and Levy, G. (1976). Pharmacokinetics of theophylline in children with asthma. Pediatrics, 58, 542-547.

Eney, R. D., and Goldstein, W. D. (1976). Compliance of chronic asthmatics with oral administration of theophylline as measured by serum and salivary levels. Pediatrics, 57, 513-517.

Hambleton, G., Weinberger, M., Taylor, J., Cavanaugh, M., Ginchansky, E., Godfrey, S., Tooley, M., Bell, T., and Greenberg, S. (1977). Comparison of cromoglycate (cromolyn) and theophylline in controlling the symptoms of chronic asthma. Lancet, 1, 381-385.

McKenzie, S. A., Baillie, E., and Godfrey, S. (1978). Effect of practical timing of dosage of theophylline blood levels in asthmatic children treated with choline theophyllinate. Archives of Disease in Childhcod, 53, 167-168.

Mitenko, P. A., and Ogilvie, R. I. (1973). Rational intravenous doses of theophylline. New England Journal o Medicine, 289, 600-603.

Nicholson, D. P., and Chick, T. W. (1973). A re-evaluation of parenteral aminophylline. American Review of Respiratory Diseases, 108, 241-247.

Schack, J. A., and Waxler, S. M. (1949). An ultraviolet spectrophotometric method for the determination of theophylline and theobromine in blood and tissues. Journal of Pharmacology and Experimental Therapeutics, 97, 283-291.

Turner-Warwick, M. (1957). Study of theophylline plasma levels after oral administration of new theophylline compounds. British Medical Journal, 2, 67-69.

Weinberger, M. M., and Bronsky, E. A. (1974). Evaluation of oral bronchodilator therapy in asthmatic children. Journal of Pediatrics, 84, 421-427.

Zwillich, C. W., Sutton, F. D., Jr., Neff, T. A., Cohn, W. M., Matthay, R. A., and Weinberger, M. M. (1975). Theophylline induced seizures in adults: correlation with serum concentration. Annals of Internal Medicine, 82, 784-787.

Correspondence to Dr S. McKenzie, Department of Paediatrics and Neonatal Medicine, Institute of Child Health, Hammersmith Hospital, Du Cane Road, London W12 0HS. 